\title{
Análise de redes sociais digitais
}

\section{Irley David Fabrício da Silva}

Mestrando do Programa de Pós-Graduação em Comunicação e Culturas Midiáticas da Universidade Federal da Paraíba e membro do grupo de pesquisa Modernização Tecnológica e Desenvolvimento Social.

E-mail: irleydavid@gmail.com

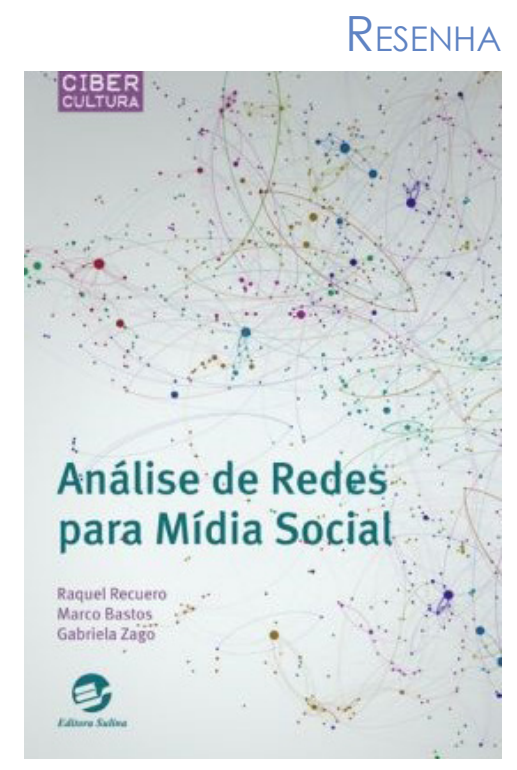

Análise de redes para a mídia social é um livro paradigmático, uma vez que foi elaborado exatamente para responder a alguns dos desafios de pesquisa no âmbito do que se convencionou chamar "ciberespaço" - em outras palavras, o ambiente virtual. A obra foi produzida e organizada por Raquel Recuero, Marco Bastos e Gabriela Zago e é, de certa forma, uma continuação do livro Redes sociais na internet (2009), da primeira autora, que já tratava do assunto. Porém, este é mais voltado para o campo conceitual, isto é, teórico; já o livro a ser analisado aqui é direcionado ao saber-fazer da abordagem teórico-metodológica da análise de redes sociais (ARS).

A obra contém 182 páginas e está dividida em quatro capítulos. De modo sucinto, os dois primeiros são mais teóricos, conceituais. São neles que os estudiosos nos fornecem a base conceitual necessária para compreendermos o passo a passo de como aplicar a abordagem metodológica da ARS; os dois últimos abordam o método de coleta e de análise de dados. Ainda nesse segundo momento, os teóricos nos mostram exemplos de aplicação de ARS em estudos no campo da política, do jornalismo e do discurso.

Antes de iniciar o primeiro capítulo, os autores apresentam uma breve introdução sobre mídia social. Na visão deles, essa introdução é primordial, uma vez que fornece os elementos essenciais para que os leitores compreendam o capítulo posterior. A priori, Recuero, Bastos e Zago buscam diferenciar o conceito de rede social offline e online. $\mathrm{Na}$ concepção deles, a primeira já existe desde os primórdios, desde que os homens passaram a interagir uns com os outros; a segunda existe desde que surgiu o ciberespaço, o ambiente de interação virtual. É importante ressaltar, dirão eles, que as redes sociais online apenas potencializaram o que já ocorria - até certo ponto - nas redes sociais offline. Além disso, para eles, vão ser as redes sociais online, especificamente a infraestrutura interacional das 
mídias sociais, ou melhor, o suporte, como o Facebook e o Twitter, que vão possibilitar ao pesquisador visualizar facilmente as redes que se formam a partir das relações e interações entre os atores sociais - possibilidade de visualização bastante precária em formação de redes sociais offline, por suas características muitas vezes efêmeras.

No primeiro capítulo, os autores buscaram definir o que é ARS, bem como apresentar as principais teorias que fundamentam essa abordagem. Para eles, "a ARS refere-se a uma abordagem de cunho estruturalista das relações entre os atores e sua função na constituição da sociedade" (p. 39). Trata-se, assim, de uma abordagem que foca o sistemismo e a estrutura social, superando, portanto, os estudos ou pensamento cartesiano, que buscava estudar as partes para entender o todo. A abordagem da ARS se sustentaria em duas teorias: uma de cunho sociológico e outra de cunho matemático. A primeira é a sociometria: "A origem dos estudos sociométricos são apontados pelos estudiosos ao trabalho de Jacob Moreno" (p. 44). Para os autores, o trabalho de Moreno era baseado numa teoria social em que os indivíduos formariam redes de conexões interpessoais. A outra teoria que também antecede a ARS é a dos grafos, que, por sua vez, foca a "representação das relações sociais a partir de métricas matemáticas" (p. 48).

O segundo capítulo enfoca os principais elementos que compõem a ARS. Os primeiros conceitos a ser tratados são "nós" e "arestas". "Nós" seriam atores sociais; indivíduos, coletivos, instituições, empresas, organizações, perfis em redes sociais, comentários, postagens etc. As "arestas" seriam as representações das conexões entre os atores sociais em determinado ambiente, como nas mídias sociais, por exemplo. Essas representações são, muitas vezes, visualizadas a partir dos grafos. Outro conceito tratado é "cluster", que significa, segundo os autores, as relações de vários "nós" dentro de determinada rede.

Além desses conceitos, vários outros são tratados ainda neste capítulo: capital social, densidade, modularidade, buraco estrutural, rede egocentrada, rede descentralizada, métricas de nó e de rede, grau de proximidade, grafos direcionados e não direcionados, entre outros. Para os autores, entender esses conceitos é essencial para quem trabalha ou deseja trabalhar com ARS.

O terceiro capítulo aborda a coleta e análise de dados, ou seja, do passo a passo de como realizar uma pesquisa segundo a abordagem da ARS. Para eles, o primeiro passo numa análise de redes sociais é a coleta de dados: é nela que o pesquisador deverá definir o que serão os "nós" (atores sociais) e as "conexões" (amizade, curtidas, comentários e menções em comentários, hashtag etc.). O segundo passo seria planejar a quantidade de dados necessária para satisfazer os objetivos de uma pesquisa - situação que varia de acordo com o estudo a ser realizado. A última fase é selecionar o software específico, 
como o Netvizz, yTK, entre outros, para coletar os dados. Depois dessa fase mais técnica, vem a fase da análise, que, segundo os pesquisadores, é feita por meio de métricas, usando softwares como o Pajek, Gephi ou NodeXL, entre outros.

Ainda no mesmo capítulo, os autores falam da ética e das limitações da abordagem da ARS. Embora eles reconheçam a eficácia dessa abordagem, também apontam seus limites. Para eles, esse processo metodológico é adequado somente para estudos cujo objetivo seja analisar a estrutura das relações sociais, dos padrões sociais. Assim, estudos que não tenham esse foco não terão uma boa recepção com esse método.

No quarto e último capítulo, os estudiosos trazem exemplos de aplicações de métricas e técnicas de análise de redes sociais para a mídia social. Recuero, Bastos e Zago buscaram mostrar de forma prática como a ARS pode auxiliar os interessados em desenvolver pesquisas e quais tipos de pesquisa em mídia social são propícias à aplicação dessa abordagem. O primeiro estudo apresentado pelos autores é no campo da política - ou melhor, no campo de participação política, colaboração cidadã. Para eles, essa é uma das áreas que vêm crescendo de forma exponencial e atraindo cada vez mais o olhar dos pesquisadores, dada a influência das redes sociais nos processos decisórios de políticas públicas. Para finalizar, os autores apresentam mais dois estudos realizados: um no campo do discurso e outro no campo do jornalismo colaborativo, ambos fenômenos ocorridos na internet.

Análise de redes para a mídia social é adequado ao nosso tempo, uma vez que busca repensar novos procedimentos metodológicos que consigam abordar os novos fenômenos e objetos de estudo que surgem no ciberespaço, nas mídias sociais. Trata-se de fenômenos emergentes que, portanto, requerem novas modalidades de resposta para capturar sua estrutura e apreeender seus sentidos. Por essa razão, a obra é rica e atual, pois busca exatamente ser uma resposta metodológica para muitos dos fenômenos ocorridos nas redes digitais. Além disso, os autores utilizam uma linguagem simples para explicar as ideias que formam a obra, sem deixar de mencionar os diversos exemplos dados, o que a torna ainda mais didática.

RECUERO, R; BASTOS, M; ZAGO, G. Análise de redes para a mídia social. Porto Alegre: Suline, 2015. 182 p. (Coleção Cibercultura). 